\title{
UNIVERSITYOF
}

FORWARD

THINKING

WESTMINSTER用

WestminsterResearch

http://www.westminster.ac.uk/westminsterresearch

\section{A Note on the Wage Effects of the 1972 Raising of the School \\ Leaving Age in Scotland and Northern Ireland \\ Buscha, F. and Dickson, M.}

This is the peer reviewed version of the following article: Buscha, F. and Dickson, M. (2018) A Note on the Wage Effects of the 1972 Raising of the School Leaving Age in Scotland and Northern Ireland, Scottish Journal of Political Economy, which has been published in final form at:

https://dx.doi.org/10.1111/sjpe.12187.

This article may be used for non-commercial purposes in accordance with Wiley Terms and Conditions for Self-Archiving.

The WestminsterResearch online digital archive at the University of Westminster aims to make the research output of the University available to a wider audience. Copyright and Moral Rights remain with the authors and/or copyright owners.

Whilst further distribution of specific materials from within this archive is forbidden, you may freely distribute the URL of WestminsterResearch: ((http://westminsterresearch.wmin.ac.uk/)).

In case of abuse or copyright appearing without permission e-mail repository@westminster.ac.uk 
A Note on the Wage Effects of the 1972 Raising of the School Leaving Age in Scotland and Northern Ireland

Franz Buscha ${ }^{1}$ and Matt Dickson ${ }^{2} \square$

${ }^{1}$ Westminster Business School, University of Westminster, 35 Marylebone

Road, London, NW1 5LS, United Kingdom

2 Department of Social and Policy Sciences, University of Bath, Claverton

Down, Bath BA2 7AY, United Kingdom Ucorresponding author

\begin{abstract}
In this note, we use the UK Labour Force Survey to estimate the wage return to an additional year of schooling for Scotland and Northern Ireland exploiting the 1972 Raising of the School Leaving Age (RoSLA). Prior literature on this topic has consistently ignored both countries in a UK context, likely due to an incorrect belief that they were not affected by the 1972 RoSLA until some years later. We demonstrate that both countries were affected by the education reform in 1972 and our estimates suggest a positive effect on hourly wages for Scotland.
\end{abstract}

Keywords: Returns to education, raising of the school leaving age, earnings, Scotland, Northern Ireland, instrumental variables (IV)

JEL classification: I21, I28, J24

\title{
1. Introduction
}

The UK literature estimating the returns to education has made frequent use of the 1972 Raising of the School Leaving Age (RoSLA) reform. This reform increased the minimum school leave age from 15 to 16 and can be used to construct a valid instrument for schooling in order to identify the causal effect of schooling on later outcomes. Using this reform previous research has found a positive impact on wages from an additional year of schooling, though the magnitude of this effect is sensitive to the dataset and estimation method used, varying between $6 \%$ and $22 \%$ (see Chevalier and Walker, 2002; Buscha and Dickson, 2012; Dickson, 2013; Grenet, 2013). There is also a broader RoSLA literature exploiting the 1972 reform to examine the causal effect of schooling on a range of outcomes including health (Clark and Royer, 2013; Silles, 2009; Powdthavee, 2010), fertility (Silles, 2011) and crime (Machin et al, 2011).

However, although the 1972 education reform was a UK-wide reform and affected all four countries (England, Wales, Scotland and Northern Ireland) at the same time, the majority of studies that use this identification strategy exclude Scotland and Northern Ireland from their analysis. It is unclear why so many studies excluded these two countries but it seems that

\footnotetext{
1 Tel: +44 (0)2079115000 x66596

E-Mail address: buschaf@wmin.ac.uk

2 Tel: +44 (0) 1225386736

E-Mail address: m.dickson@bath.ac.uk
} 
many authors incorrectly believed that the raising of the school leaving age from 15 to 16 took place in 1972 only for England and Wales and for the other countries it was implemented at a later date.

In this study we contend that this was not the case and explore the 1972 RoSLA in Scotland and Northern Ireland. We argue that, contrary to popular understanding in the literature, there was a significant positive education shock in both Scotland and Northern Ireland in 1972 and that this reform can thus be used as a credible instrument to either a) boost samples sizes in any UK analysis or b) estimate separate education effects for Scotland and Northern Ireland.

\section{Previous Research on Wage Returns to Education}

Table 1 reviews the relevant UK literature. Presented are recent studies that have estimated wage returns using the 1972 RoSLA reform. It can be observed that almost all these studies focus only on English and Welsh geographies and ignore Scotland and Northern Ireland. The "founding" study for the UK returns to education instrumental variables literature is Harmon and Walker (1995) who do use all four countries. However, they miss-assign the relevant 1972 RoSLA date for Scotland to 1976 rather than 1972. Part of this confusion may be due a 1976 Act that changed the leaving dates in Scotland and compelled some students who previously were leaving earlier to remain until the end of May from that year onwards. A more detailed history of the 1972 RoSLA and its implementation can be found in Woodin et al. (2013).

Due to the influential nature of the original Harmon and Walker study it is possible that subsequent studies simply assumed that their approach was correct and excluded Scotland from their analysis when using the 1972 reform. Alternatively, it may be that Scotland was excluded due to the differences in the education system compared to England and Wales. However, high-stakes secondary school exams are taken at age 16 in both jurisdictions hence the impact of the raising of the minimum leaving age to 16 is likely to be similar despite nominally different qualifications being taken. In addition, while Northern Ireland was included in the Oreopoulos (2006) study of the earlier raising of the school leaving age from 14 to 15 in the UK, it appears that Northern Ireland was either ignored or forgotten in later studies that exploit the 1972 reform.

Table 1: A Review of the Impact of the 1972 School Leaving Age Reform on Male Wages

\begin{tabular}{|c|c|c|c|c|c|}
\hline Study & Data & RoSLA & $\begin{array}{l}\text { Effect of RoSLA on } \\
\text { education }\end{array}$ & $\begin{array}{l}\text { Wage return to } \\
\text { one year of } \\
\text { schooling using } \\
\text { RoSLA IV }\end{array}$ & Countries \\
\hline $\begin{array}{l}\text { Harmon } \\
\text { and Walker } \\
(1995)\end{array}$ & $\begin{array}{l}\text { Pooled Family } \\
\text { Expenditure } \\
\text { Survey } 1978 \text { to } \\
1986\end{array}$ & $\begin{array}{l}1947 \\
\text { and } \\
1972\end{array}$ & $\begin{array}{l}0.541 \text { additional } \\
\text { years of schooling } \\
\text { for the } 1947 \text { change } \\
\text { and } 0.110 \\
\text { additional years for } \\
\text { the } 1972 \text { change }\end{array}$ & $\begin{array}{l}\text { IV estimate of } \\
15 \% \text { for hourly } \\
\text { wages }\end{array}$ & $\begin{array}{l}\text { England, } \\
\text { Wales, } \\
\text { Scotland and } \\
\text { Northern }\end{array}$ \\
\hline
\end{tabular}




\begin{tabular}{|c|c|c|c|c|c|}
\hline Study & Data & RoSLA & $\begin{array}{l}\text { Effect of RoSLA on } \\
\text { education }\end{array}$ & $\begin{array}{l}\text { Wage return to } \\
\text { one year of } \\
\text { schooling using } \\
\text { RoSLA IV }\end{array}$ & Countries \\
\hline & & & & & $\begin{array}{l}\text { Ireland } \\
\text { combined }\end{array}$ \\
\hline $\begin{array}{l}\text { Chevalier } \\
\text { and Walker } \\
\text { (2002) }\end{array}$ & $\begin{array}{l}\text { British } \\
\text { Household } \\
\text { Panel Survey } \\
1991 \text { to } 1996\end{array}$ & 1972 & Not reported & $\begin{array}{l}\text { IV estimate of } \\
17-20 \% \text { for } \\
\text { hourly wages }\end{array}$ & $\begin{array}{l}\text { England and } \\
\text { Wales } \\
\text { combined }\end{array}$ \\
\hline $\begin{array}{l}\text { Dickson } \\
\text { and Smith } \\
\text { (2011) }\end{array}$ & $\begin{array}{l}\text { Pooled } \\
\text { Quarterly } \\
\text { Labour Force } \\
\text { Survey } 1993 \text { to } \\
2010\end{array}$ & 1972 & $\begin{array}{l}\text { Proportion with no } \\
\text { academic } \\
\text { qualifications fell by } \\
0.071 \text {; those with } \\
\text { level } 1 \text { qualifications } \\
\text { increased by } 0.047 ; \\
\text { those with level } 2 \\
\text { qualifications } \\
\text { increased by } 0.041 \text {. } \\
\text { No effect on level } \\
3+\text { qualifications }\end{array}$ & $\begin{array}{l}\text { No effect on } \\
\text { hourly wages }\end{array}$ & $\begin{array}{l}\text { England and } \\
\text { Wales } \\
\text { combined }\end{array}$ \\
\hline $\begin{array}{l}\text { Buscha } \\
\text { and } \\
\text { Dickson } \\
\text { (2012) }\end{array}$ & $\begin{array}{l}\text { UK Household } \\
\text { Longitudinal } \\
\text { Study } 2011\end{array}$ & 1972 & $\begin{array}{l}0.225 \text { additional } \\
\text { years of schooling }\end{array}$ & $\begin{array}{l}\text { IV estimate of } \\
22 \% \text { for hourly } \\
\text { wages }\end{array}$ & $\begin{array}{l}\text { England and } \\
\text { Wales } \\
\text { combined }\end{array}$ \\
\hline $\begin{array}{l}\text { Grenet } \\
\text { (2013) }\end{array}$ & $\begin{array}{l}\text { Pooled } \\
\text { Quarterly } \\
\text { Labour Force } \\
\text { Survey } 1993 \text { to } \\
2004\end{array}$ & 1972 & $\begin{array}{l}0.274 \quad \text { additional } \\
\text { years of schooling }\end{array}$ & $\begin{array}{l}\text { IV estimate of } \\
6-7 \% \text { for hourly } \\
\text { wages }\end{array}$ & $\begin{array}{l}\text { England and } \\
\text { Wales } \\
\text { combined }\end{array}$ \\
\hline
\end{tabular}

\section{Identification Strategy: the $\mathbf{1 9 7 2}$ Raising of the School Leaving Age in Scotland and Northern Ireland}

The expansion of compulsory schooling to age 16 in 1972 for England and Wales was achieved via a statutory instrument (Order in Council) on the $22^{\text {nd }}$ of March $1972^{3}$ that implemented the statue of the Education Acts 1944 and 1962. For Scotland, the 1972 RoSLA became operational via an Order in Council entitled 'The Raising of the School Leaving Age (Scotland) 1972'. The instrument was enacted on the $20^{\text {th }}$ January $1972^{4}$ and legislated to "...raise from fifteen to sixteen the upper limit of the 'school age', as defined in section 32(1) of the Education (Scotland) Act 1962" effective from the $1^{\text {st }}$ of September 1972 across Scotland. A report by the HM Inspectors of Schools (Scottish Education Department, 1976) provides further insight into the Scottish 1972 RoSLA; it states that although issues such as apathy and truancy occurred amongst those compelled to remain in school, overall the

\footnotetext{
3 http://www.legislation.gov.uk/uksi/1972/444/pdfs/uksi_19720444_en.pdf

4 http://www.legislation.gov.uk/uksi/1972/59/pdfs/uksi_19720059_en.pdf
} 
RoSLA implementation in Scotland was relatively well organised. The majority of schools were adequately staffed, well-resourced and had enough accommodation to cope with the sudden increase in student numbers.

Northern Ireland implemented the 1972 RoSLA via an Order in Council on the $14^{\text {th }}$ April $1972^{5}$ entitled 'Raising of School Leaving Age Order (Northern Ireland) 1972' whose purpose was to raises the upper limit of compulsory schooling to age 16 from $1^{\text {st }}$ September 1972 . All four UK countries therefore experienced the same school leaving age at the same time.

We exploit the exogenous variation in schooling induced by this reform to identify the causal effect of education on wages, and following the more recent literature we use a regression discontinuity design approach to the instrumental variables (IV) methodology. As per the best practice recommended by Imbens and Lemieux (2008) and Gelman and Imbens (2014), we fit a linear regression function to observations within distance $h$ on either side of the discontinuity point ( $1^{\text {st }}$ September 1957$)$

$$
\begin{aligned}
& \begin{array}{l}
\min _{\alpha_{\text {pre 1957:Bpre 1957 }}} \sum_{\mathrm{i}: \mathrm{c}-\mathrm{h}<\mathrm{X}_{\mathrm{i}}<\mathrm{c}}\left(\mathrm{Y}_{\mathrm{i}}-\alpha_{\text {pre 1957 }}-\beta_{\text {pre 1957. }}\left(\mathrm{X}_{\mathrm{i}}-\mathrm{C}\right)\right)^{2} \\
\text { and }
\end{array}
\end{aligned}
$$

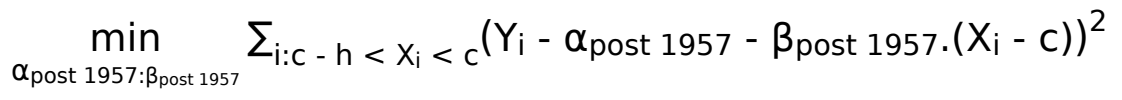

Where $Y_{i}$ is log hourly wages, $X_{i}$ is the number of months an individual is born before/after the $1^{\text {st }}$ September 1957 discontinuity, the as and $\beta$ s are the regression intercepts and slope values computed for data in the region surrounding the discontinuity, $c$, with bandwidth, $h$. These values are calculated twice, once for the left-hand side of $c$ (born pre-September 1957) and once for the right-hand side (born post-September 1957) of $c$. The intercept values at the discontinuity, $\mu_{\text {pre } 1957(c)}$ and $\mu_{\text {post } 1957(c) \text {, can then }}$ be computed by:

and

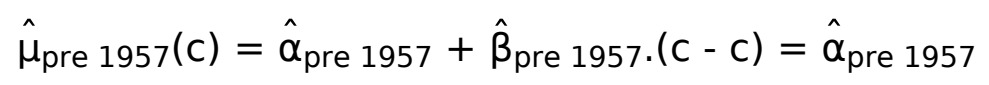

$$
\hat{\mu}_{\text {post } 1957(c)}=\hat{\alpha}_{\text {post } 1957}+\hat{\beta}_{\text {post 1957. }}(c-c)=\hat{\alpha}_{\text {post } 1957}
$$

Given these estimates we can then compute the treatment effect of 1972 RoSLA log hourly wages $Y_{i}$ as follows:

$$
\hat{\beta}_{\text {wage }}=\hat{\alpha}_{\text {post } 1957-\hat{\alpha}_{\text {pre }} 1957}
$$

We use an analogous procedure to calculate the impact of the reform on years of schooling, denoted $\hat{\beta}_{\text {school, }}$ and can then recover an estimate of the impact of an additional year of schooling as the ratio of these two reduced form coefficients: $\hat{\beta}_{\mathrm{IV}}=\hat{\beta}_{\text {wage }} / \hat{\beta}_{\text {school }}$.

\footnotetext{
${ }^{5}$ https://www.thegazette.co.uk/Belfast/issue/2777/page/139
} 


\section{Data and the impact of the 1972 RoSLA on Schooling}

We follow Grenet (2013) and use the quarterly UK Labour Force Survey (LFS), pooled from 1993q1 to 2011q4 inclusive. The LFS is the largest regular household survey in the UK and is designed to be representative of the population living in private households, with approximately 60,000 households responding each quarter. We restrict the earnings estimations to include only information from an individual's last interview. We select individuals resident in England, Wales, Scotland and Northern Ireland and exclude those who were born outside of the UK unless they moved to the UK prior to commencing their secondary education. To ensure our estimates are comparable to the majority of the prior literature, we restrict our analysis to men only, exclude those who are self-employed, those working less than 20 hours per week and those who first left full-time education after the age of 25 . We calculate average gross hourly pay excluding overtime in main job and deflate earnings into $2012 \mathrm{Es}$. Finally, we trim the earnings distribution to remove the top and bottom $1 \%$ of the distribution.

In terms of educational impact, it is well established that the 1972 RoSLA had a significant impact of around one-third of a year additional schooling for young people in England and Wales. We repeat this estimate and at the same time expand the analysis to Scotland and Northern Ireland. Results are presented in Figure 1. We find a significant positive education event occurring in Scotland and Northern Ireland at the same time as the 1972 RoSLA in England and Wales. Average years of schooling increases by approximately one-quarter whilst the proportion of children staying in school beyond age 15 jumps to over $95 \%$. This, in addition to the historical evidence provided in section 3, confirms that Scotland and Northern Ireland were not excluded from the 1972 UK RoSLA.

Figure 1: The 1972 RoSLA effect on education 

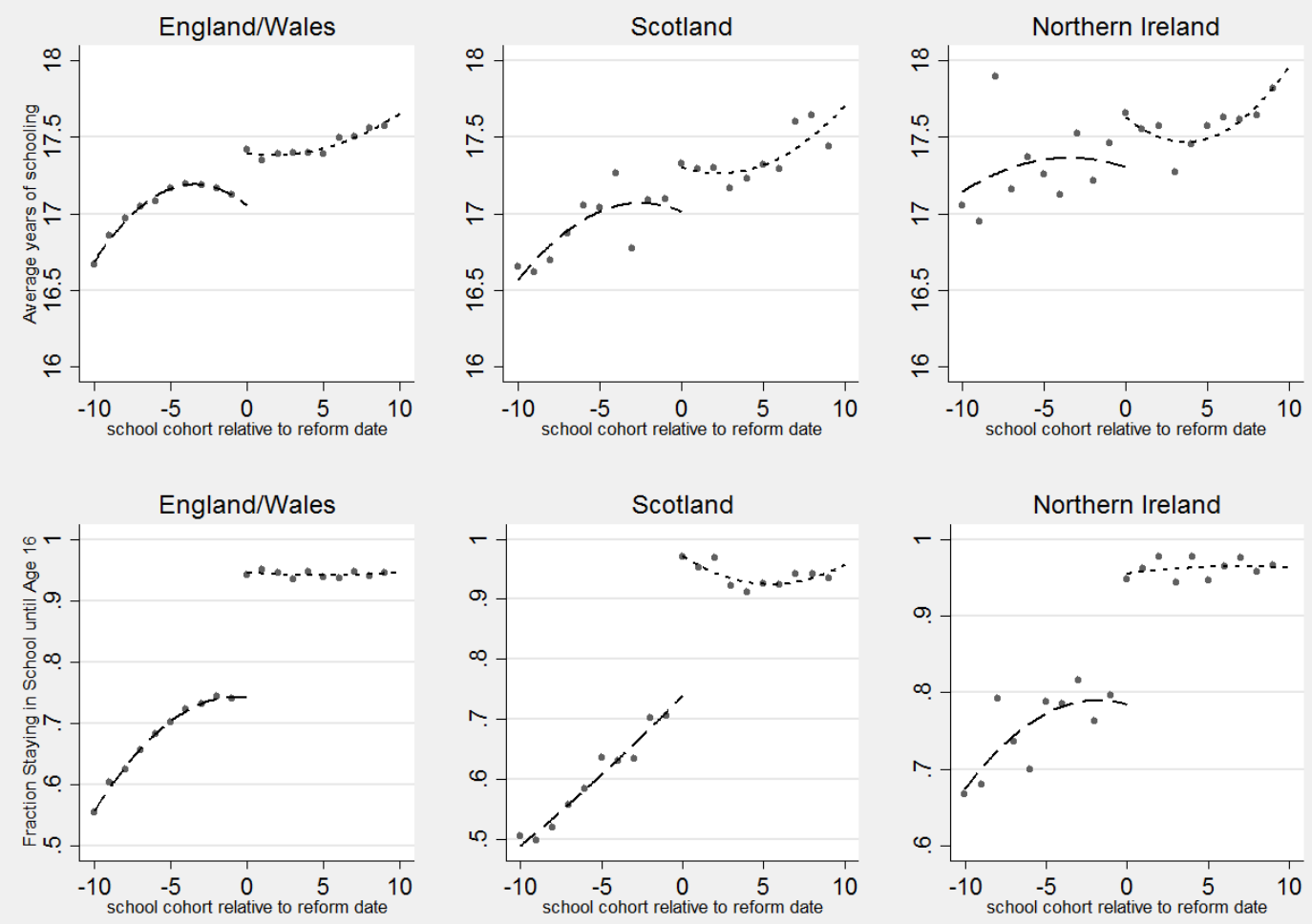

Source: LFS 1993-2011, cohort averages with quadratic fit, men only

\section{The impact of the 1972 RoSLA on Wages}

To examine the effect of the 1972 RoSLA on wages in Scotland and Northern Ireland we first plot average hourly pay around the education discontinuity. Figure 2 presents these plots for England and Wales and for Scotland and Northern Ireland. The England/Wales and Scotland graphs have a striking similarity and suggest a positive effect from the education discontinuity. For Northern Ireland wages levels are lower and the trend pattern pre-reform less clear, moreover the smaller sample size for Scotland, and even more so for Northern Ireland, results in more variation around the trend. We now proceed to estimate the effect of 1972 RoSLA on wages via a regression discontinuity (RD) framework.

Figure 2: The 1972 RoSLA effect on log hourly pay
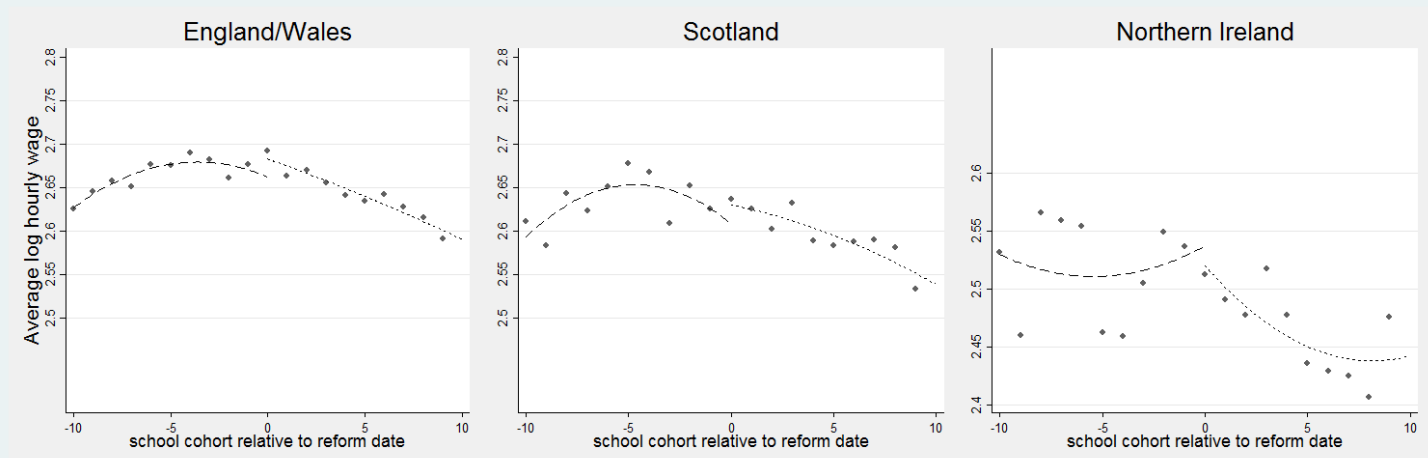

Source: LFS 1993-2011, cohort averages with quadratic fit, men only

As outlined above, we use local linear regression in a local region near the discontinuity to estimate the effect of the 1972 RoSLA on education and 
earnings. However, rather than using year of birth averages, as presented in the Figure 1 and 2, we use month of birth as our running variable. This implies that our bandwidth choices must be multiples of 12 to avoid within school-year month of birth effects (see Crawford et al, 2010). Therefore, we present results for bandwidths of 12, 24, 36, 48, 60 and 72 months, and in each case we use a rectangular kernel. We run initial regressions to remove country-specific macro time effects and carry out all the analysis on the wage residuals from these regressions. ${ }^{6}$

Results are presented in Table 2. Our preferred estimates are those in the higher bandwidth range as this is where estimated coefficients appear to stabilise. We estimate a reduced form effect of approximately $2 \%$ of 1972 RoSLA on log hourly wages in England and Wales. Reduced form effects for years of schooling in England and Wales are approximately 0.3 additional years whilst the proportion of individuals staying on in post-15 education jumps by approximately 0.22 . Results for Scotland are of similar magnitude with effects of $2 \%$ on hourly wages, approximately 0.3 additional years of schooling and a post-15 education jump of approximately 0.27 . However, standard errors are larger due to smaller sample sizes making only the educational results statistically significant. For Northern Ireland estimates are erratic and do not appear to stabilise. This primarily due to the low available sample size.

Using the reduced form estimates in Table 2 we can calculate the Wald (IV) estimates, for example the 60 months bandwidth gives a return to schooling in England and Wales of $(0.022 / 0.317) * 100=6.8 \%$. These estimates are presented in Table 3 . Our results show that we can replicate Grenet's (2013) findings for England and Wales exactly, estimating a general range of $6-7 \%$ increase in hourly wages per additional year of schooling. These estimates apply to a pooled age range of approximately 35-54 years of age and should be considered as an average return across this period of the lifecycle. For Scotland, the smaller sample size leads to significantly larger standard errors and as such the estimates are not statistically significant at conventional levels. However, the magnitude of the estimated wage effect for Scotland mirror those of the England and Wales, particularly for the larger bandwidths of 60 months or more, and we argue that with a larger sample size we would most likely find similar coefficients with smaller standard errors.

An alternative interpretation could be that weak identification has led us to find relatively 'noisy zero's', with no true effects of the reform apparent. However, we reject such an interpretation based on the contextual evidence from previous studies and from our own results here. It is well established in this literature that RoSLA increased the average years of schooling by between 0.20 and 0.35 years for England and Wales (see Silles, 2009, 2011; Machin et al, 2011; Grenet, 2013; Clark and Royer, 2013) and an increase of this size is evident in our findings for Scotland. Both visually in Figure 2 and statistically in Table 2, it is clear that a positive education shock of this magnitude affected young people in Scotland at the same time as the effect occurred in England and Wales. Given these common empirical findings for

${ }^{6}$ Results are almost identical using raw log hourly wage as the dependent variable. 
education we might expect the wage impacts to also be mirrored, and this is indeed suggested in Figure 2 and Table 2. Thus although the large standard errors prevent even the higher bandwidth wage estimates reaching statistical significance for Scotland, the similarity in point estimates at higher bandwidths, taken with the graphical evidence, suggests the wage impact may indeed have been replicated in Scotland.

Using the ratio of the reduced form and first stage coefficients, we cautiously estimate that the return to hourly wages is approximately 5-6\% per additional year of schooling for Scotland; very similar to the estimates for England and Wales. Unfortunately, for Northern Ireland the small sample size leads to results that are too unstable to draw firm conclusions.

\section{Conclusion}

This note has argued that the education reforms that increased the minimum school leaving age to 16 took place in all four countries in the UK in 1972 and not at a later date in Scotland. We have presented both historical and empirical evidence that this is the case, showing that all four countries experienced similar positive education effects which in turn resulted in similar sized wage effects for Scotland and England and Wales. The wage return in Northern Ireland proved more difficult to identify due to the small sample size available. The important conclusion is that the 1972 reform did indeed affect all four countries at the same time and thus future studies making use of the 1972 reform to estimate the impact of additional schooling on various wage and non-wage outcomes should not exclude Scotland and Northern Ireland from their data. 
Table 2: RD Estimates of the effect of the 1972 RoSLA on residual log hourly wages and years of schooling, various bandwidths: pooled LFS data 1993q1-2011q4

\begin{tabular}{|c|c|c|c|c|c|c|c|c|c|c|c|c|c|c|c|}
\hline & \multicolumn{5}{|c|}{ England/Wales } & \multicolumn{5}{|c|}{ Scotland } & \multicolumn{5}{|c|}{ Northern I reland } \\
\hline & $\begin{array}{l}\text { Bandwidth } \\
\text { (months) }\end{array}$ & $\begin{array}{l}\text { Logwage } \\
\text { residuals }\end{array}$ & $\begin{array}{l}\text { Years of } \\
\text { schooling }\end{array}$ & $\begin{array}{l}\text { Remain } \\
\text { post-15 }\end{array}$ & $\mathrm{N}$ & $\begin{array}{l}\text { Bandwidth } \\
\text { (months) }\end{array}$ & $\begin{array}{l}\text { Log wage } \\
\text { residuals }\end{array}$ & $\begin{array}{l}\text { Years of } \\
\text { schooling }\end{array}$ & $\begin{array}{l}\text { Remain } \\
\text { post-15 }\end{array}$ & $\mathrm{N}$ & $\begin{array}{l}\text { Bandwidth } \\
\text { (months) }\end{array}$ & $\begin{array}{l}\text { Logwage } \\
\text { residuals }\end{array}$ & $\begin{array}{l}\text { Years of } \\
\text { schooling }\end{array}$ & $\begin{array}{l}\text { Remain } \\
\text { post-15 }\end{array}$ & $\mathrm{N}$ \\
\hline $\begin{array}{l}\text { Caff. } \\
\text { Std Err. }\end{array}$ & 12 & $\begin{array}{l}0.024 \\
(0.020)\end{array}$ & $\begin{array}{l}0.403^{* \alpha+k} \\
(0.102)\end{array}$ & $\begin{array}{l}0.247^{* 2 * 1} \\
(0.015)\end{array}$ & 10,281 & 12 & $\begin{array}{l}0.056 \\
(0.058)\end{array}$ & $\begin{array}{l}0.19 \\
(0.278)\end{array}$ & $\begin{array}{l}0.316^{* 1 *} \\
(0.045)\end{array}$ & 1,185 & 12 & $\begin{array}{l}0.061 \\
(0.114)\end{array}$ & $\begin{array}{l}0.050 \\
(0.710)\end{array}$ & $\begin{array}{l}0.120 \\
(0.080)\end{array}$ & 255 \\
\hline $\begin{array}{l}\text { Caff. } \\
\text { Std Err. }\end{array}$ & 24 & $\begin{array}{l}0.030^{*} \\
(0.014)\end{array}$ & $\begin{array}{l}0.428^{* k *} \\
(0.070)\end{array}$ & $\begin{array}{l}0.223^{* 1 *} \\
(0.010)\end{array}$ & 20,542 & 24 & $\begin{array}{l}0.026 \\
(0.040)\end{array}$ & $\begin{array}{l}0.282 \\
(0.204)\end{array}$ & $\begin{array}{l}0.295^{* * *} \\
(0.031)\end{array}$ & 2,316 & 24 & $\begin{array}{l}-0.003 \\
(0.083)\end{array}$ & $\begin{array}{l}0.106 \\
(0.491)\end{array}$ & $\begin{array}{l}0.108 \\
(0.061)\end{array}$ & 482 \\
\hline $\begin{array}{l}\text { Coff. } \\
\text { Std Err. }\end{array}$ & 36 & $\begin{array}{l}0.024^{*} \\
(0.011)\end{array}$ & $\begin{array}{l}0.375^{* 1 \alpha k} \\
(0.057)\end{array}$ & $\begin{array}{l}0.219^{\text {kak }} \\
(0.008)\end{array}$ & 30,625 & 36 & $\begin{array}{l}-0.001 \\
(0.033)\end{array}$ & $\begin{array}{l}0.146 \\
(0.165)\end{array}$ & $\begin{array}{l}0.248^{* k k} \\
(0.025)\end{array}$ & 3,527 & 36 & $\begin{array}{l}-0.027 \\
(0.072)\end{array}$ & $\begin{array}{l}0.159 \\
(0.391)\end{array}$ & $\begin{array}{l}0.164^{* k} \\
(0.048)\end{array}$ & 715 \\
\hline $\begin{array}{l}\text { Câff. } \\
\text { Std Err. }\end{array}$ & 48 & $\begin{array}{l}0.028^{* *} \\
(0.010)\end{array}$ & $\begin{array}{l}0.349+1 * k \\
(0.049)\end{array}$ & $\begin{array}{l}0.221^{* 1 *} \\
(0.007)\end{array}$ & 40,995 & 48 & $\begin{array}{l}0.001 \\
(0.029)\end{array}$ & $\begin{array}{l}0.359 * \\
(0.145)\end{array}$ & $\begin{array}{l}0.261^{* * *} \\
(0.022)\end{array}$ & 4,659 & 48 & $\begin{array}{l}-0.038 \\
(0.062)\end{array}$ & $\begin{array}{l}0.211 \\
(0.338)\end{array}$ & $\begin{array}{l}0.180^{121 *} \\
(0.043)\end{array}$ & 953 \\
\hline $\begin{array}{l}\text { Coff. } \\
\text { Std Err. }\end{array}$ & 60 & $\begin{array}{l}0.022^{*} \\
(0.009)\end{array}$ & $\begin{array}{l}0.317^{* k *} \\
(0.044)\end{array}$ & $\begin{array}{l}0.211^{* 1 * k} \\
(0.006)\end{array}$ & 51,750 & 60 & $\begin{array}{l}0.020 \\
(0.026)\end{array}$ & $\begin{array}{l}0.332 * * \\
(0.128)\end{array}$ & $\begin{array}{l}0.272^{* * * k} \\
(0.019)\end{array}$ & 5,876 & 60 & $\begin{array}{l}-0.048 \\
(0.057)\end{array}$ & $\begin{array}{l}0.146 \\
(0.302)\end{array}$ & $\begin{array}{l}0.171^{* 1 * k} \\
(0.038)\end{array}$ & 1,195 \\
\hline $\begin{array}{l}\text { Carff. } \\
\text { Std Err. }\end{array}$ & 72 & $\begin{array}{l}0.018 * \\
(0.008) \\
\end{array}$ & $\begin{array}{l}0.281^{* * *} \\
(0.040) \\
\end{array}$ & $\begin{array}{l}0.206^{121 *} \\
(0.006) \\
\end{array}$ & 62,219 & 72 & $\begin{array}{l}0.014 \\
(0.023) \\
\end{array}$ & $\begin{array}{l}0.278 * \\
(0.118) \\
\end{array}$ & $\begin{array}{l}0.263^{* 1 *} \\
(0.018) \\
\end{array}$ & 7,040 & 72 & $\begin{array}{l}-0.021 \\
(0.052) \\
\end{array}$ & $\begin{array}{l}0.112 \\
(0.279) \\
\end{array}$ & $\begin{array}{l}0.158^{* 1 * 1} \\
(0.035) \\
\end{array}$ & 1,422 \\
\hline & A verage & 0.023 & 0.357 & 0.221 & & A verage & 0.020 & 0.265 & 0.276 & & A verage & -0.012 & 0.131 & 0.150 & \\
\hline
\end{tabular}

return 
Table 3: IV Estimates of the effect of the 1972 RoSLA on log hourly wages, various bandwidths: pooled LFS data 1993q1-2011q4

\begin{tabular}{|c|c|c|c|c|c|c|c|}
\hline & $\begin{array}{l}\text { Bandwidth } \\
\text { (months) }\end{array}$ & $\begin{array}{l}\quad \text { England } \\
\text { IV return to } \\
1 \text {-year of } \\
\text { schooling }\end{array}$ & $\begin{array}{l}\text { and Wales } \\
\text { IV return to } \\
\text { remaining } \\
\text { post-15 }\end{array}$ & $\begin{array}{l}\text { Scot } \\
\text { IV return to } \\
\text { 1-year of } \\
\text { schooling }\end{array}$ & $\begin{array}{l}\text { tland } \\
\text { IV return to } \\
\text { remaining } \\
\text { post-15 }\end{array}$ & $\begin{array}{l}\text { Northern } \\
\text { IV return to } \\
\text { 1-year of } \\
\text { schooling }\end{array}$ & $\begin{array}{l}\text { n Ireland } \\
\text { IV return to } \\
\text { remaining } \\
\text { post-15 }\end{array}$ \\
\hline $\begin{array}{l}\text { Coeff. } \\
\text { Std. Err. }\end{array}$ & 12 & $\begin{array}{l}0.060 \\
(0.052)\end{array}$ & $\begin{array}{l}0.097 \\
(0.081)\end{array}$ & $\begin{array}{l}0.295 \\
(0.528)\end{array}$ & $\begin{array}{l}0.177 \\
(0.185)\end{array}$ & $\begin{array}{l}1.220 \\
(17.473)\end{array}$ & $\begin{array}{l}0.508 \\
(1.009)\end{array}$ \\
\hline $\begin{array}{l}\text { Coeff. } \\
\text { Std. Err. }\end{array}$ & 24 & $\begin{array}{l}0.070 * \\
(0.035)\end{array}$ & $\begin{array}{l}0.135 * \\
(0.063)\end{array}$ & $\begin{array}{l}0.092 \\
(0.157)\end{array}$ & $\begin{array}{l}0.088 \\
(0.136)\end{array}$ & $\begin{array}{l}-0.028 \\
(0.794)\end{array}$ & $\begin{array}{l}-0.028 \\
(0.769)\end{array}$ \\
\hline $\begin{array}{l}\text { Coeff. } \\
\text { Std. Err. }\end{array}$ & 36 & $\begin{array}{l}0.064 * \\
(0.031)\end{array}$ & $\begin{array}{l}0.110 * \\
(0.050)\end{array}$ & $\begin{array}{l}-0.007 \\
(0.226)\end{array}$ & $\begin{array}{l}-0.004 \\
(0.133)\end{array}$ & $\begin{array}{l}-0.170 \\
(0.616)\end{array}$ & $\begin{array}{l}-0.165 \\
(0.442)\end{array}$ \\
\hline $\begin{array}{l}\text { Coeff. } \\
\text { Std. Err. }\end{array}$ & 48 & $\begin{array}{l}0.080 * * \\
(0.031)\end{array}$ & $\begin{array}{l}0.127 * * \\
(0.045)\end{array}$ & $\begin{array}{l}0.003 \\
(0.081)\end{array}$ & $\begin{array}{l}0.004 \\
(0.111)\end{array}$ & $\begin{array}{l}-0.180 \\
(0.412)\end{array}$ & $\begin{array}{l}-0.211 \\
(0.348)\end{array}$ \\
\hline $\begin{array}{l}\text { Coeff. } \\
\text { Std. Err. }\end{array}$ & 60 & $\begin{array}{l}0.069 * \\
(0.030)\end{array}$ & $\begin{array}{l}0.104 * \\
(0.043)\end{array}$ & $\begin{array}{l}0.060 \\
(0.082)\end{array}$ & $\begin{array}{l}0.074 \\
(0.096)\end{array}$ & $\begin{array}{l}-0.329 \\
(0.784)\end{array}$ & $\begin{array}{l}-0.281 \\
(0.339)\end{array}$ \\
\hline $\begin{array}{l}\text { Coeff. } \\
\text { Std. Err. }\end{array}$ & 72 & $\begin{array}{l}0.064 * \\
(0.030)\end{array}$ & $\begin{array}{l}0.087^{*} \\
(0.039)\end{array}$ & $\begin{array}{l}0.050 \\
(0.085)\end{array}$ & $\begin{array}{l}0.053 \\
(0.088)\end{array}$ & $\begin{array}{l}-0.188 \\
(0.659)\end{array}$ & $\begin{array}{l}-0.133 \\
(0.330)\end{array}$ \\
\hline
\end{tabular}

$* \mathrm{p}<0.05, * * \mathrm{p}<0.01, * * * \mathrm{p}<0.001$. Estimates based on local linear regression using rectangular kernel. LFS: 1993q1-2011q4, men only. This equates to an age range of 35-54 and results indicate an average return over these years. Initial regressions of log hourly wages on country specific year dummies are run and the residuals recovered and used as the dependent variable. 


\section{References}

Buscha, F. and Dickson, M. 2012. The raising of the school leaving age: returns in later life. Economics Letters, Vol 117, No. 2, pp. 389-393.

Chevalier, A. and Walker, I. 2002. Further estimates of the returns to education in the UK. In Harmon, C., Walker, I. and Westergard-Nielsen, W. (eds) The Returns to Education Across Europe, Edward Elgar.

Clark, D. and Royer, H. 2013. The Effect of Education on Adult Mortality and Health: Evidence from Britain, American Economic Review, Vol. 103, No.6, pp. 2087-2120.

Crawford, C., Dearden, L. and Meghir, C. 20120. When You Are Born Matters: The Impact of Date of Birth on Educational Outcomes in England. Working Paper No. W10/06, Institute of Fiscal Studies, London, UK.

Dickson, M. 2013. The Causal Effect of Education on Wages Revisited, Oxford Bulletin of Economics and Statistics, Vol. 75, No. 4, pp. 477-498.

Dickson, M. and Smith, S. 2011. What determines the return to education: an extra year or a hurdle cleared? Economics of Education Review, Vol. 30, No. 6, pp. 1167-1176.

Gelman, A. and Imbens, G. 2014. Why high-order polynomials should not be used in regression discontinuity designs. Working Paper no. 20405, National Bureau of Economic Research, Cambridge, Massachusetts.

Grenet, J. 2013. Is extending compulsory schooling alone enough to raise earnings? Evidence from French and British compulsory schooling laws. The Scandinavian Journal of Economics, Vol. 115, No. 1, pp. 176-210.

Harmon, C. and Walker, I. 1995. Estimates of the economic return to schooling for the United Kingdom, American Economic Review, Vol. 85, No. 5, pp. 12781286.

Imbens, G. and Lemieux, T. 2008. Regression discontinuity designs: a guide to practice. Journal of Econometrics, Vol. 142, pp. 615-635.

Machin, S., Marie, O. and Vujic, S. 2011. The crime reducing effect of education. The Economic Journal, Vol. 121, pp. 463-484.

Oreopoulos, P. 2006. Estimating average and local average treatment effects of education when compulsory schooling laws really matter, American Economic Review, Vol. 96, No. 1:152-75.

Powdthavee, N. 2010. Does Education Reduce the Risk of Hypertension? Estimating the Biomarker Effect of Compulsory Schooling in England, Journal of Human Capital, Vol. 4, No. 2, pp. 173-202. 
Scottish Education Department, 1976, The Raising of the School Leaving Age in Scotland: A Report by HM Inspectors of Schools 1976, Edinburgh.

Silles, Mary. 2009. The causal effect of education on health: evidence from the United Kingdom. Economics of Education Review, Vol. 28, pp. 122-128.

Silles, M. 2011. The effect of schooling on teenage childbearing: evidence using changes in compulsory education laws. Journal of Population Economics, Vol. 24, No. 2, pp. 761-777.

Woodin, T., McCulloch, G., and Cowan, S. 2013. Secondary Education and the Raising of the School-leaving Age : Coming of Age? (Secondary Education in a Changing World). Palgrave Macmillan.

\section{Declarations}

Ethics Approval and Consent to Participate

This project has ethical approval from the University of Bath Dept. for Social and Policy Sciences Research Ethics Committee. The study uses pre-anonymised secondary data, no individual participants in the UK Quarterly Labour Force Survey can be identified.

Consent for Publication

The study uses pre-anonymised secondary data, no individual participants in the UK Quarterly Labour Force Survey can be identified.

List of Abbreviations

IV Instrumental Variables

LFS Labour Force Survey

RD Regression Discontinuity

RoSLA Raising of the School Leaving Age

Availability of Data and Materials

The UK Quarterly Labour Force Survey is available to academic researchers registered with the UK Data Service, see https://www.ukdataservice.ac.uk We make use of special licence version of the data available to Office for National Statistics Approved Researchers only. As such we are unable to deposit the data used in this study.

Competing Interests

None.

Funding

None.

Authors' Contributions

Franz Buscha 50\%

Matt Dickson 50\%

Acknowledgements 
We would like to thank Silvia Barcellos and Leandro Carvalho for highlighting the timing of the 1972 RoSLA in Scotland, and Tom Woodin and Gary McCulloch for contributing historical information on the 1972 RoSLA. 